\title{
HEAT AND TEMPERATURE EXPERIMENT DESIGNS TO SUPPORT STUDENTS' CONCEPTION ON NATURE OF SCIENCE
}

\author{
Eka Cahya Prima ${ }^{1}$ iD, Setiya Utari ${ }^{2}$ D, Didi Teguh Chandra $^{2}$ D, Lilik Hasanah ${ }^{2}$ iD, \\ Dadi Rusdiana ${ }^{2}$ iD \\ ${ }^{1}$ Department of Science Education, Faculty of Mathematics and Science Education, \\ Universitas Pendidikan Indonesia (Indonesia) \\ ${ }^{2}$ Department of Physics Education, Faculty of Mathematics and Science Education, \\ Universitas Pendidikan Indonesia (Indonesia) \\ ekacabyaprima@upi.edu, setiyautari@yahoo.co.id, diditeguschandra@upi.edu, lilikhasanab@upi.edu, \\ dadirusdiana@upi.edu
}

Received March 2018

Accepted July 2018

\section{Abstract}

Constructing student's scientific literacy is still a challenge for the developing country. PISA 2015 report on scientific literacy showed that Indonesia was positioned at $62^{\text {th }}$ out of 70 countries. According to this result, the students are only able to explain the simple science phenomenon because some learning activities have not followed good scientific inquiry as a fundamental aspect of the nature of science. To overcome the problem, PISA 2015 stated that teachers are suggested to design well-structured laboratory activities that make actual scientific concepts and ideas, and help students make the connection among the hands-on activities, scientific ideas and real-life problems. Moreover, the student's conception of the nature of scientific knowledge is required to help a student become a scientifically literate person. This work aims to construct science knowledge and contextual problems to support students' conception of the nature of science. In the case of the physics subject, eight new heat and temperature experiment designs are proposed to construct students' scientific literacy in high schools. The aspects of scientific literacy on experiment designs are developed based on PISA 2015 frameworks.

Keywords - Heat and temperature, Nature of science, Science education.

\section{To cite this article:}

Prima, E.C., Utari, S., Chandra, D.T., Hasanah, L., \& Rusdiana, D. (2018). Heat and temperature experiment designs to support students' conception on nature of science. Journal of Technology and Science Education, 8(4), 453-472. https://doi.org/10.3926/jotse.419

\section{Introduction}

The increase in the population growth rate may affect several problems. The lack of people understanding on scientific insight to make a good decision might cause the social problems and natural disasters such as an unemployment, a colonialist, a poverty, a flooding, a fire, and so on. As a citizen, we have to concern on how to solve these problems by improving the people-scientific mindset. Moreover, PISA (2015) study 
on scientific literacy showed that Indonesia was positioned at $62^{\text {th }}$ out of 70 countries participating in the survey. The student's understanding of scientific investigations has to be gained so that they are able to adapt to a modernization. Art (2003) viewed that the modernization of social life was closely related to the development of science and technology. This transformation cannot be realized so that the new generations are able to understand the new issues and to decide based on scientifically reasonable evidence. Therefore, a literate citizen should be able to evaluate the quality of scientific information on his participation in civic and cultural affairs, and economic productivity (Miller, 1983). To realize this condition, learning activities should not only focus on what students know about science, but also concern on how they use science to decide based on scientific information. Consequently, a good teacher must have an awareness of his duties as an educator. He must facilitate students finding several ways of developing their own potential because this is the child's right to obtain the best opportunity (Eisenkraft, 2010).

Science is a good particular way to understand the natural phenomena. Students should learn how to use their way of thinking to investigate the factual issues (DeBoer, 2000). Therefore, Dewey (1904) argued that the inquiry-based learning presented a real experience using scientific ways of building knowledge or solving problems. The student's conception on 'nature of science' are required to be carried out because the terms relate to an epistemology of science, science as a way of knowing, or the values to the scientific knowledge development (Abd-El-Khalick \& Lederman, 2000). Compared to other aspects of scientific literacy, an adequate understanding of the nature of science (NOS) plays the most important role in improving the scientific literacy (American Association for the Advancement of Science - AAAS, 1990). The scientific literacy refers to the ability of the individual to read, comprehend, and express his opinion on scientific matters are required to become a scientifically literate person (Miller, 1983). National Research Council (1996) initiated scientific literacy including (1) concepts and processes for physics and biology, (2) inquiry scientific methods, (3) science application in daily life, and (4) social and environmental implications and technology development. Scientific literacy is nowadays a goal of science education (Wenning, 2006). By considering the large scope of scientific literacy, the assessing direct improvement of scientific literacy is quite complicated to be accomplished. PISA (2015) strongly recommend that the most important thing to be trained to the student is by implementing experiments and hands-on activities. This work can help students develop a conceptual understanding of scientific ideas and transferable skills, such as critical thinking. This investigation will construct students' way of knowing as a critical aspect of the conception of the nature of science.

The nature of science refers to the science as a way of knowing, epistemology of science, or the beliefs and value inherent to the scientific knowledge development (Lederman, Lederman \& Antink, 2013). A consensus view of the nature of science objectives is taken from the documents of eight international science standards (McComas, Clough \& Almazroa, 1998). For instance, scientists are able to formulate and test their explanations of nature using observation, experiments, and theoretical and mathematical models. In areas where active research being pursued, it is normal for a scientist to differ from one another about the interpretation of the theory or evidence. Accordingly, the examination includes reviewing the experimental procedures, examining the evidence, identifying faulty reasoning, pointing out scientific interpretation, and suggesting alternative reasons for the same observations. McComas et al. (1998) also suggested that requiring that preservice teachers conduct more experience on laboratory research projects are often believed to be the solution to improve prospective science teachers' understanding of the nature of science. Lederman, Abd-El-Khalick, Bell and Schwartz (2002) found that (78\%) explicitly stated the misconception that scientific theories become laws when it was proven through repeated testing. Interestingly, it was also believed that laws were proven true and theories were tentative, either because not enough data are available or because scientists are unable to design experiments or apparatus to test theories adequately. It is a challenge to a teacher to design good experiments and to set up apparatus correctly.

The teacher's difficulty in showing a real natural phenomenon will affect to construct students' knowledge. Teachers must guarantee that the scientific content is meaningful and important to students, not as lifeless 
abstractions (DeBoer, 2000). They should conduct this process using inquiry-based or constructivist teaching. Duschl (1987) states that teachers themselves need to have an adequate understanding of the nature of science. Therefore, the teachers conduct 'real science' investigations of their own design and use the results to generate inquiry-based lessons for the classroom (Lederman, et al., 2002). To improve the nature of science, PISA (2015) suggested that the teachers need to design well-structured laboratory activities that make actual scientific concepts and ideas. It will help students make the connections among the scientific ideas, hands-on activities, and real-life problems. Students should also be made aware that while conducting these activities, they are manipulating objects as well as ideas. However, presenting contextual problems in terms of the real situation is a challenge to a science teacher (Karim, Prima, Utari, Saepuzaman \& Nugaha, 2017). The reason, why a teacher feels difficult serving this equipment, is a lecturer weakness in providing the real scientific experiences to the prospective students (Niess, 2005). The educational curricula must engage the student to be able to design good science experiments. In order to design the science experiments, we refer to the instructional model developed by Dick \& Carey (Dick, 1996) as seen in Figure 1.

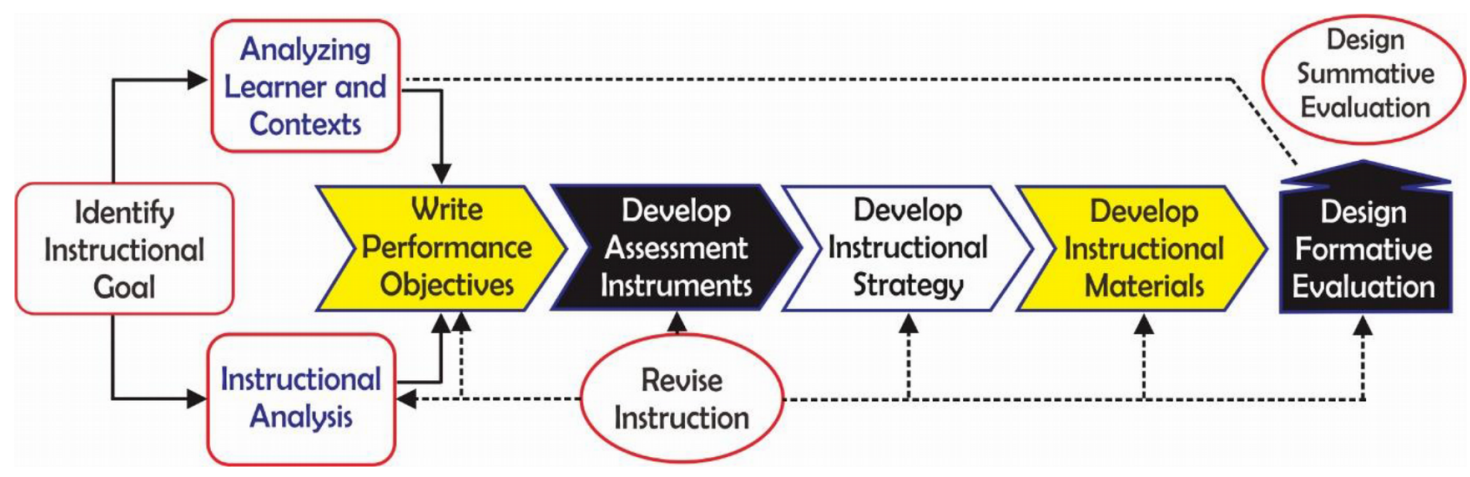

Figure 1. Model of instructional design by Dick \& Carey (Dick, 1996)

During identifying learning achievements, the lesson not only refers to the competencies required by the curriculum but also considers the conception of the nature of science (Organisation for Economic Co-operation and Development \& PISA, 2013). The characteristics of learners should be recognized to provide wise ways of building their knowledge so that students are interested and not easily frustrated. They also behave with good attitudes and positive perceptions (Marzano, Pickering \& McTighe, 1993). For example, a teacher firstly shows a contextual phenomenon related to the expected concept. He composes learning outcomes as a base for developing instrument and learning strategies. This learning strategy is a basis for developing learning media required for the learning process. Finally, both formative and summative tests are composed to evaluate students' conception of the nature of science.

Heat and temperature concepts are interesting to be investigated by students because the phenomenon can be found in daily life. The concepts are also presented in the PISA 2015 Scientific Literacy Benchmark such as questions about global warming, starlight and lip gloss (PISA, 2015). Moreover, the increase of automation technology makes a farmer think the best solution to design the best condition for farming and harvesting. The researchers also seek the best strategy to overcome the negative impacts of global warming. The cases must be investigated scientifically in order to infer the concept and to propose the alternative solutions. Understanding the heat and temperature contributes to a more informed and intelligent experience with the natural world as expected in the Goals of the Science Teaching (DeBoer, 2000). To achieve this goal, students are guided to understand that heat consists of random motion and the vibrations of atoms, molecules, and ions. The higher the temperature, the greater the atomic or molecular motion. In nature, everything tends to become less organized and less orderly over time. Moreover, in all energy transfers, the overall effect is that the energy is spread out uniformly. For instance, the energy transfer comes from hotter to cooler objects by conduction, radiation, or convection and the warming of our surroundings when we burn fuels. Clough (2011) presented the contextual fact that 
beyond our homes, massive road networks now span our nation, and clean water and sanitation systems serve our cities and towns. Power plants and grids provide reliable electricity to heat and light our homes. It is suggested that this understanding will improve the student's conception of the nature of science as a fundamental part of scientific literacy.

In fact, it is found that students have a rather unsatisfactory understanding of heat and temperature (Shirish, Saurabhee, Madhura, Savita \& Hemachandra, 2015). To overcome the problem, the previous works have reported the investigation of heat transfer for educational purposes. An open inquiry (OI)-based learning experience is presented to investigate the process of energy exchange by thermal radiation (Nicola, Claudio \& Onofrio-Rosario, 2014). The learning method allowed us to analyse the teachers' feedback from a pedagogical point of view. Yeung-Chung (2007) recommended the strategy to engage students in constructing concepts by giving the problems based on scientific demonstration. Shirish et al. (2015) have designed a module of five activities to improve student's understanding of thermal equilibrium. Moreover, Kevin (2000) implemented the experiment through discussion to acquire the necessary concepts in thermal physics. The key concepts consist of thermal equilibrium, the notion of flow of heat energy, and the ability to differentiate between heat and temperature. Williams, Nguyen and Mangan (2017) present a case study of a teacher's experience in implementing an inquiry approach using information technologies to support student inquiry learning on the temperature of the water during evaporating and time to evaporate. Rodríguez-García, Astrain-Ulibarrena, Martínez-Echeverri, Aranguren-Garacochea and Pérez-Artieda (2013) built and validated a practical bench to study cooling and thermal generation. It has also been simulated thermoelectric refrigeration or generation. In this way, students can reach a new technology that is not normally seeing in their previous studies. We have previously reported heat transfer laboratory kit using temperature sensor-based Arduino ${ }^{\mathrm{TM}}$ for educational purpose (Prima, Karim, Utari, Ramdani, Putri \& Darmawati, 2017). In this work, we will propose two types of media based on heat and temperature experiment used to construct science knowledge and to serve problem-solving laboratory. The developed experiment designs refer to PISA 2015 frameworks. The context domains consist of the personal context showing the personal energy use and the scientific aspects, while the local context presents the development of new materials and equipment.

\section{Methods}

This qualitative-descriptive research is adopted to overview the design of instructional media on the topic of heat and temperature. The designed media are analyzed based on related aspects such as the curriculum content (content and competence), potential resources of school and students, and contextual issues for developing projects. The quality of designed media to support the nature of science is evaluated using a laboratory test. The expert judgment is performed based on the specification of developed media. The media will be improved based on a small-scale test which involves schools within a limited area. A consensus view of the nature of science objectives extracted from eight international science standards documents (Lederman et al., 2013).

The heat and temperature topic are chosen to design experiments for supporting student's conception on the nature of science. Based on our observation, teachers in some schools tend to deliver this concept through conventional lecturing. They rarely use appropriate media. Whereas, we can find several contextual problems that can be demonstrated in an apperception stage. Therefore, the analysis of curriculum and scientific literacy framework is required to develop the heat and temperature experiment design as discussed in Table 1. Moreover, the complete experiment designs on heat and temperature supporting the student's nature of science are described in Table 2 . 


\begin{tabular}{|c|c|c|c|c|}
\hline $\begin{array}{l}\text { Competence in } \\
\text { Indonesian } \\
\text { Curriculum }\end{array}$ & Topics & $\begin{array}{c}\text { Scientific literacy } \\
\text { Domains } \\
\text { (PISA 2015 } \\
\text { Framework) }\end{array}$ & $\begin{array}{c}\text { Context Domain } \\
\text { (PISA 2015 Framework) }\end{array}$ & Media being developed \\
\hline $\begin{array}{l}\text { Analyze the effect of } \\
\text { heat and heat transfer } \\
\text { including thermal } \\
\text { characteristics of } \\
\text { materials, specific heat, } \\
\text { and heat conductivity } \\
\text { to be applied in a daily } \\
\text { life } \\
\text { Plan and conduct an } \\
\text { experiment about the } \\
\text { thermal characteristics } \\
\text { of materials especially } \\
\text { related to specific heat } \\
\text { and conductivity, and } \\
\text { present the result } \\
\text { including its physical } \\
\text { meaning }\end{array}$ & $\begin{array}{l}\text { Temperature and } \\
\text { thermal expansion } \\
\text { The relation } \\
\text { between heat and } \\
\text { temperature } \\
\text { including its } \\
\text { object phase } \\
\text { Black principle } \\
\text { Heat transfer by } \\
\text { conduction, } \\
\text { convection, and } \\
\text { radiation }\end{array}$ & $\begin{array}{l}\text { Describe nature } \\
\text { phenomena } \\
\text { Evaluate and plan } \\
\text { the scientific } \\
\text { experiment } \\
\text { Interpret data and } \\
\text { scientific evidence }\end{array}$ & $\begin{array}{l}\text { Equipment: making a } \\
\text { thermometer manually } \\
\text { Scientific aspect based } \\
\text { on students' interest: } \\
\text { constructing digital } \\
\text { thermometer utilizing } \\
\text { microcontroller, making } \\
\text { egg incubator } \\
\text { New materials: } \\
\text { determining liquid type } \\
\text { based on the thermal } \\
\text { expansion coefficient, } \\
\text { determining the best } \\
\text { criteria for machine } \\
\text { cooling liquid, making a } \\
\text { bimetal model } \\
\text { Using energy wisely: } \\
\text { determining the price to } \\
\text { provide a cup of coffee, } \\
\text { how to minimize the heat } \\
\text { loss }\end{array}$ & $\begin{array}{l}\text { Phenomenon and } \\
\text { experiment are closely } \\
\text { related to the thermal } \\
\text { expansion happened in } \\
\text { solid, liquid, and gas, then } \\
\text { determine the expansion } \\
\text { coefficient of a material } \\
\text { Phenomenon showing the } \\
\text { tendency of given heat } \\
\text { towards the increased } \\
\text { temperature of an object, } \\
\text { mass. The result will be } \\
\text { used to investigate specific } \\
\text { heat. } \\
\text { The phenomenon of heat } \\
\text { transfer by conduction, } \\
\text { convection, and radiation } \\
\text { to perform an experiment } \\
\text { on heat transfer } \\
\text { The media are related to } \\
\text { the context domain being } \\
\text { selected }\end{array}$ \\
\hline
\end{tabular}

Table 1. Analysis of curriculum and scientific literacy framework 2015 in terms of heat and temperature experiment designs

\begin{tabular}{|c|c|c|c|c|c|c|c|}
\hline No & Experiments & $\begin{array}{c}\text { Student's } \\
\text { Competences }\end{array}$ & Assumptions & \begin{tabular}{|c|} 
NOS \\
Objectives
\end{tabular} & Details & \begin{tabular}{c|} 
Related Daily \\
Problems
\end{tabular} & $\begin{array}{c}\text { Allocated } \\
\text { Time }\end{array}$ \\
\hline 1 & $\begin{array}{l}\text { Demonstratio } \\
\mathrm{n} \text { activity to } \\
\text { construct the } \\
\text { concept of } \\
\text { thermal } \\
\text { expansion and } \\
\text { temperature }\end{array}$ & $\begin{array}{l}\text { Identify a problem } \\
\text { of physical means } \\
\text { of thermal } \\
\text { expansion } \\
\text { Describe nature } \\
\text { phenomena }\end{array}$ & $\begin{array}{l}\text { Students might } \\
\text { not consider that } \\
\text { the process of } \\
\text { thermal } \\
\text { expansion is } \\
\text { reversible and it } \\
\text { requires the heat. } \\
\text { Students might } \\
\text { think that his } \\
\text { hand can be } \\
\text { used to measure } \\
\text { the temperature }\end{array}$ & $\begin{array}{l}\text { Science is an } \\
\text { attempt to } \\
\text { explain } \\
\text { natural } \\
\text { phenomena }\end{array}$ & $\begin{array}{l}\text { Type: Demonstration to } \\
\text { construct science knowledge } \\
\text { Materials used: balloon, digital } \\
\text { thermometer, thermometer, set } \\
\text { of the burner, a beaker glass, } \\
\text { Erlenmeyer flask, digital } \\
\text { thermometer } \\
\text { Procedures } \\
\text { A. balloon is being heated } \\
\text { 1. Close the Erlenmeyer flask by } \\
\text { a balloon } \\
\text { 2. Put the Erlenmeyer in a water- } \\
\text { filled beaker glass } \\
\text { 3. Put the beaker glass on the set } \\
\text { of burner } \\
\text { 4. Put the sensor of a digital } \\
\text { thermometer in the beaker glass } \\
\text { 5. Heat the beaker glass and } \\
\text { observe the expansion of the } \\
\text { balloon and the digital } \\
\text { thermometer } \\
\text { B. thermometer is held by a } \\
\text { hand } \\
\text { 1. Hold the bottom edge of the } \\
\text { thermometer } \\
\text { 2. Observe the temperature on }\end{array}$ & $\begin{array}{l}\text { Why is a high- } \\
\text { voltage power } \\
\text { line installed } \\
\text { rather loose? } \\
\text { The engineer } \\
\text { must pay } \\
\text { attention to a } \\
\text { gap between } \\
\text { two bridges. } \\
\text { A gap between } \\
\text { glass and } \\
\text { frame in the } \\
\text { window. }\end{array}$ & 30 mins \\
\hline
\end{tabular}




\begin{tabular}{|c|c|c|c|c|c|c|c|}
\hline No & Experiments & $\begin{array}{c}\text { Student's } \\
\text { Competences }\end{array}$ & Assumptions & $\begin{array}{c}\text { NOS } \\
\text { Objectives }\end{array}$ & Details & $\begin{array}{l}\text { Related Daily } \\
\text { Problems }\end{array}$ & $\begin{array}{c}\text { Allocated } \\
\text { Time }\end{array}$ \\
\hline & & & & & $\begin{array}{l}\text { the thermometer display } \\
\text { 3. Hang the thermometer and } \\
\text { observe the thermometer } \\
\text { display } \\
\text { C. a balloon is being blown } \\
\text { 1. Provide the balloon, and blow } \\
\text { it } \\
\text { 2. Check the balloon } \\
\text { temperature before blowing. } \\
\text { 3. Observe the size of the blown } \\
\text { balloon } \\
\text { 4. Check the balloon } \\
\text { temperature now. }\end{array}$ & & \\
\hline 2 & $\begin{array}{l}\text { Experiment } \\
\text { design to } \\
\text { construct the } \\
\text { concept of } \\
\text { linear thermal } \\
\text { expansion as } \\
\text { the working } \\
\text { principle of } \\
\text { the } \\
\text { thermometer }\end{array}$ & $\begin{array}{l}\text { Design } \\
\text { experimental } \\
\text { procedures to test } \\
\text { the prediction of } \\
\text { the nature of the } \\
\text { thermal expansion }\end{array}$ & $\begin{array}{l}\text { Materials used in } \\
\text { thermometer } \\
\text { behave a linear } \\
\text { thermal } \\
\text { expansion } \\
\text { Students might } \\
\text { think that every } \\
\text { liquid can be } \\
\text { used as a } \\
\text { material for the } \\
\text { thermometer } \\
\text { The increase of } \\
\text { temperature in } \\
\text { alcohol inside } \\
\text { the test tube is } \\
\text { the same as the } \\
\text { increase of } \\
\text { temperature in } \\
\text { water detected } \\
\text { by a digital } \\
\text { thermometer }\end{array}$ & $\begin{array}{l}\text { Scientists are } \\
\text { creative }\end{array}$ & $\begin{array}{l}\text { Type: Project to construct } \\
\text { science knowledge } \\
\text { Materials used: Alcohol, } \\
\text { coloring agent, test tube, rubber } \\
\text { stopper, set of the burner, digital } \\
\text { thermometer, glass straws } \\
\text { Procedures } \\
\text { 1. Fill the test tube by the } \\
\text { colored alcohol } \\
\text { 2. Close the test tube by the } \\
\text { glass straw-equipped rubber } \\
\text { stopper. } \\
\text { 3. Put the test tube inside a } \\
\text { water-filled beaker glass. } \\
\text { 4. Put a beaker glass on the set } \\
\text { of burner } \\
\text { 5. Check the length expansion as } \\
\text { the increase of the } \\
\text { temperature. } \\
\text { 6. Compare the liquid expansion } \\
\text { to the expansion of the } \\
\text { alcohol inside thermometer. }\end{array}$ & $\begin{array}{l}\text { Why is water } \\
\text { not be used as } \\
\text { a material for } \\
\text { the } \\
\text { thermometer? } \\
\text { How does the } \\
\text { island relate to } \\
\text { the special } \\
\text { characteristics } \\
\text { of water } \\
\text { expansion? }\end{array}$ & 30 mins \\
\hline 3 & $\begin{array}{l}\text { The effect of } \\
\text { alcohol } \\
\text { concentration } \\
\text { towards linear } \\
\text { thermal } \\
\text { expansion }\end{array}$ & $\begin{array}{l}\text { Investigate new } \\
\text { materials for the } \\
\text { scientific } \\
\text { improvement }\end{array}$ & $\begin{array}{l}\text { Alcohol is fully } \\
\text { soluble in water } \\
\text { The thermal } \\
\text { expansion } \\
\text { coefficient of } \\
\text { water is the non- } \\
\text { proportional } \\
\text { response of } \\
\text { temperature } \\
\text { change. }\end{array}$ & $\begin{array}{l}\text { New } \\
\text { knowledge } \\
\text { must be } \\
\text { reported } \\
\text { clearly and } \\
\text { openly }\end{array}$ & $\begin{array}{l}\text { Type: Project to solve the } \\
\text { problem } \\
\text { Materials used: Alcohol, } \\
\text { coloring agent, test tube, rubber } \\
\text { stopper, set of the burner, digital } \\
\text { thermometer, glass straws } \\
\text { Procedures } \\
\text { 1. The stages follow the second } \\
\text { experiment. } \\
\text { 2. The materials used are } \\
\text { elaborated by changing the } \\
\text { concentration of alcohol: } \\
\text { water of } 90 \%, 70 \% \text {, and } 30 \% \\
\text { (v/v). } \\
\text { 3. Volume thermal coefficients } \\
\text { of the mixture are } \\
\text { investigated. } \\
\text { 4. Make a decision about what } \\
\text { will happen if the alcohol as a } \\
\text { thermometer material is } \\
\text { changed by the mixture. }\end{array}$ & $\begin{array}{l}\text { Why is syrup } \\
\text { or carbonated } \\
\text { mixture not } \\
\text { fully filled in } \\
\text { the bottle? } \\
\text { How does it } \\
\text { happen if we } \\
\text { put it under } \\
\text { sunlight? } \\
\text { How to put } \\
\text { the scale and } \\
\text { calibrate a } \\
\text { thermometer? }\end{array}$ & 60 mins \\
\hline 4 & $\begin{array}{l}\text { Equipment } \\
\text { design to } \\
\text { exercise } \\
\text { problem- } \\
\text { solving }\end{array}$ & $\begin{array}{l}\text { Understanding the } \\
\text { nature and } \\
\text { importance of } \\
\text { technology and } \\
\text { the relationship }\end{array}$ & $\begin{array}{l}\text { The potential } \\
\text { difference of the } \\
\text { LM35 sensor } \\
\text { behaves the } \\
\text { proportional }\end{array}$ & $\begin{array}{l}\text { Science and } \\
\text { technology } \\
\text { impact each } \\
\text { other }\end{array}$ & $\begin{array}{l}\text { Type: Project to solve the } \\
\text { problem } \\
\text { Materials used: Scaled } \\
\text { thermometer, Bar } \\
\text { thermometer, ruler, stand, }\end{array}$ & $\begin{array}{l}\text { The Celcius } \\
\text { and Fahrenheit } \\
\text { thermometers } \\
\text { measure the } \\
\text { same }\end{array}$ & 90 mins \\
\hline
\end{tabular}




\begin{tabular}{|c|c|c|c|c|c|c|c|}
\hline No & Experiments & $\begin{array}{c}\text { Student's } \\
\text { Competences }\end{array}$ & Assumptions & $\begin{array}{c}\text { NOS } \\
\text { Objectives }\end{array}$ & Details & $\begin{array}{c}\text { Related Daily } \\
\text { Problems }\end{array}$ & $\begin{array}{c}\text { Allocated } \\
\text { Time }\end{array}$ \\
\hline & $\begin{array}{l}\text { laboratory } \\
\text { activities on } \\
\text { making a } \\
\text { thermometer }\end{array}$ & $\begin{array}{l}\text { between } \\
\text { technology and } \\
\text { science. }\end{array}$ & $\begin{array}{l}\text { response to the } \\
\text { temperature } \\
\text { change. } \\
\text { Students } \\
\text { understand the } \\
\text { electrical circuit } \\
\text { of temperature } \\
\text { sensor } \\
\text { installation } \\
\text { before running } \\
\text { the experiment. } \\
\text { The } \\
\text { thermometer } \\
\text { liquid materials } \\
\text { behave the } \\
\text { proportional } \\
\text { response to the } \\
\text { temperature } \\
\text { change. }\end{array}$ & & $\begin{array}{l}\text { Arduino Uno, Hook up wires, } \\
\text { protoboard, potentiometer } 10 \\
\mathrm{k} \Omega, \mathrm{LM} 35 \text { temperature sensor, } \\
16 \times 2 \text { LCD Display, Printer } \\
\text { USB, Computer } \\
\text { Procedures } \\
\text { Making analog thermometer } \\
\text { 1. the bar and the scaled } \\
\text { thermometers are installed in } \\
\text { parallel } \\
\text { 2. A ruler is required to set the } \\
\text { level of material expansion at } \\
\text { least on two conditions: at a } \\
\text { freezing and a boiling points } \\
\text { of water in } 1 \text { atmospheric } \\
\text { pressure. } \\
\text { 3. A transparent tape can be } \\
\text { attached on the bar } \\
\text { thermometer so that the scale } \\
\text { can be indicated. } \\
\text { Making digital thermometer } \\
\text { The details of the experimental } \\
\text { procedure are described below } \\
\text { the Table } 2 \text {. }\end{array}$ & $\begin{array}{l}\text { environment } \\
\text { temperature. It } \\
\text { shows the } \\
\text { different } \\
\text { values. Do you } \\
\text { think that the } \\
\text { degree of } \\
\text { molecular } \\
\text { vibration is } \\
\text { different? } \\
\text { When you are } \\
\text { fever, how do } \\
\text { you use the } \\
\text { digital } \\
\text { thermometer } \\
\text { to measure } \\
\text { your body } \\
\text { temperature? }\end{array}$ & \\
\hline 5 & $\begin{array}{l}\text { Experiment } \\
\text { design to } \\
\text { construct the } \\
\text { concept of } \\
\text { the linear } \\
\text { temperature } \\
\text { expansion } \\
\text { coefficient of } \\
\text { some metals }\end{array}$ & $\begin{array}{l}\text { Conduct scientific } \\
\text { experiment on } \\
\text { thermal expansion } \\
\text { Collect } \\
\text { meaningful data, } \\
\text { organize, and } \\
\text { analyze data } \\
\text { accurately and } \\
\text { precisely }\end{array}$ & $\begin{array}{l}\text { The solid } \\
\text { materials behave } \\
\text { the proportional } \\
\text { response to the } \\
\text { temperature } \\
\text { change. }\end{array}$ & $\begin{array}{l}\text { Science is an } \\
\text { attempt to } \\
\text { explain } \\
\text { natural } \\
\text { phenomena } \\
\text { Scientists are } \\
\text { creative }\end{array}$ & $\begin{array}{l}\text { Type: Experiment to construct } \\
\text { science knowledge } \\
\text { Materials used: } \\
\text { Musschenbroek apparatus, video } \\
\text { recorder, digital vernier caliper, } \\
\text { electric heater, thermocouple } \\
\text { type K, thermometer } \\
\text { Procedures } \\
\text { 1. Put the copper, zinc, brass, } \\
\text { steel, and stainless steel on the } \\
\text { Musschenbroek apparatus. } \\
\text { 2. The metal rod edge is firmly } \\
\text { contacted to the depth } \\
\text { measuring blade of digital } \\
\text { vernier caliper. } \\
\text { 3. Set the display of length as } \\
\text { zero for digital vernier } \\
\text { caliper. } \\
\text { 4. The digital thermocouple is } \\
\text { also equipped with a rod } \\
\text { surface. } \\
\text { 5. Record the initial temperature } \\
\text { of metals. } \\
\text { 6. To supply the uniform } \\
\text { conduction, the electric heater } \\
\text { is contacted on another edge } \\
\text { of the metal rod. } \\
\text { 7. Plug in the electric heater. } \\
\text { 8. The temperature change and } \\
\text { rod expansion are recorded by } \\
\text { the video recorder. }\end{array}$ & $\begin{array}{l}\text { How is the } \\
\text { railroad } \\
\text { constructed to } \\
\text { prevent the } \\
\text { thermal } \\
\text { bending? } \\
\text { How does the } \\
\text { iron not over } \\
\text { overheat? }\end{array}$ & 60 mins \\
\hline 6 & $\begin{array}{l}\text { Experiment } \\
\text { designs of a } \\
\text { bimetal strip } \\
\text { model }\end{array}$ & $\begin{array}{l}\text { Do the action to } \\
\text { obtain valid } \\
\text { evidence. }\end{array}$ & $\begin{array}{l}\text { The bimetal strip } \\
\text { is bent only due } \\
\text { to the thermal } \\
\text { coefficient } \\
\text { difference. }\end{array}$ & $\begin{array}{l}\text { Scientists are } \\
\text { creative }\end{array}$ & $\begin{array}{l}\text { Type: Project to solve the } \\
\text { problem } \\
\text { Materials used: Paper, } \\
\text { aluminum sheet, electric heater, } \\
\text { glue } \\
\text { Procedures } \\
\text { 1. Cut the paper and aluminum } \\
\text { sheet with the size of } 5.0 \times \\
0.75 \mathrm{~cm} \text {. } \\
\text { 2. Glue one side of paper and }\end{array}$ & $\begin{array}{l}\text { How is the } \\
\text { bimetal } \\
\text { applied to the } \\
\text { thermostat } \\
\text { and } \\
\text { thermometer? } \\
\text { How does the } \\
\text { bimetal bend } \\
\text { its shape? }\end{array}$ & 15 mins \\
\hline
\end{tabular}




\begin{tabular}{|c|c|c|c|c|c|c|c|}
\hline No & Experiments & $\begin{array}{c}\text { Student's } \\
\text { Competences }\end{array}$ & Assumptions & \begin{tabular}{|c|} 
NOS \\
Objectives \\
\end{tabular} & Details & $\begin{array}{c}\text { Related Daily } \\
\text { Problems }\end{array}$ & $\begin{array}{c}\text { Allocated } \\
\text { Time }\end{array}$ \\
\hline & & & & & $\begin{array}{l}\text { aluminium sheet to be } \\
\text { attached to each other. } \\
\text { 3. Let the materials dye for } 5 \\
\text { minute } \\
\text { 4. Turn on the electric heater } \\
\text { 5. Put the handmade bimetal on } \\
\text { the surface of the electric } \\
\text { heater }\end{array}$ & & \\
\hline 7 & $\begin{array}{l}\text { Thermostat- } \\
\text { equipped egg } \\
\text { incubator }\end{array}$ & $\begin{array}{l}\text { Demonstrate an } \\
\text { understanding of } \\
\text { scientific concepts } \\
\text { in different } \\
\text { situations. }\end{array}$ & $\begin{array}{l}\text { The thermostat } \\
\text { has a great } \\
\text { sensitivity to } \\
\text { response the } \\
\text { environment } \\
\text { temperature } \\
\text { change. } \\
\text { The temperature } \\
\text { detected by the } \\
\text { thermocouple } \\
\text { sensor } \\
\text { represents the } \\
\text { uniformly } \\
\text { distributed air } \\
\text { temperature. } \\
\text { The thermostat } \\
\text { keeps the air } \\
\text { temperature } \\
\text { constant during } \\
\text { the incubation. }\end{array}$ & \begin{tabular}{|l|} 
Scientific \\
ideas affect \\
social \\
culture
\end{tabular} & $\begin{array}{l}\text { Type: Project to solve the } \\
\text { problem } \\
\text { Materials used: Thermocouple, } \\
\text { Willhi TM thermostat, digital } \\
\text { thermometer, wire, lamp, lamp } \\
\text { holder, switch, plastic box, } \\
\text { Procedures } \\
\text { 1. Install the probe of the } \\
\text { K-type thermocouple to the } \\
\text { NTC port } 7 \text { and } 8 \text { of the } \\
\text { thermostat. } \\
\text { 2. Connect the power wire to } \\
\text { power port } 3 \text { and } 4 \text { of the } \\
\text { thermostat. } \\
\text { 3. Connect the lamp wire to the } \\
\text { load port } 1 \text { and } 2 \text { of the } \\
\text { thermostat } \\
\text { 4. Open this link for detail } \\
\text { schematic circuit } \\
\text { https://www.youtube.com/w } \\
\text { atch?v=BpwAk69Aoag } \\
\text { 5. Press RST key to switch on } \\
\text { and off, press the RST key on } \\
\text { the power-off state once to } \\
\text { turn on, on the power-on } \\
\text { state, press the RST key for } \\
\text { three seconds and hold on, } \\
\text { then it will be off. } \\
\text { 6. Press the SET key once to } \\
\text { enter the temperature control } \\
\text { setting, press } \boldsymbol{\Delta} \text { or } \nabla \text { button } \\
\text { to adjust, press } \boldsymbol{\Delta} \text { or } \boldsymbol{\nabla} \\
\text { button for three seconds and } \\
\text { hold to enter the fast adjusting } \\
\text { mode, press the SET key } \\
\text { again to exit setting mode }\end{array}$ & $\begin{array}{l}\text { How to } \\
\text { incubate the } \\
\text { eggs effectively } \\
\text { so that the egg } \\
\text { hatches on } \\
\text { time? } \\
\text { How the } \\
\text { Inflatable } \\
\text { incubator help } \\
\text { save } \\
\text { premature } \\
\text { babies? }\end{array}$ & 90 mins \\
\hline 8 & $\begin{array}{l}\text { Experiment } \\
\text { design for } \\
\text { investigating } \\
\text { the effect of } \\
\text { thermal } \\
\text { insulation }\end{array}$ & $\begin{array}{l}\text { Conduct scientific } \\
\text { experiment on } \\
\text { thermal insulation }\end{array}$ & $\begin{array}{l}\text { The greater the } \\
\text { heat received by } \\
\text { the system, the } \\
\text { little the heat lost } \\
\text { to the } \\
\text { environment. } \\
\text { The efficiency } \\
\text { of electric heater } \\
\text { machine is } \\
\text { constant during } \\
\text { the experiment. }\end{array}$ & \begin{tabular}{|l|} 
Science is an \\
attempt to \\
explain \\
natural \\
phenomena
\end{tabular} & $\begin{array}{l}\text { Type: Project to solve the } \\
\text { problem } \\
\text { Materials used: Electric heater, } \\
\text { WANF Watt meter, water, } \\
\text { insulation materials including } \\
\text { styrofoam, sawdust, dacron, } \\
\text { cartoon, calorimeter, and digital } \\
\text { thermometer } \\
\text { Procedures } \\
\text { 1. Measure the diameter of the } \\
\text { container } \\
\text { 2. Prepare the blanket of the } \\
\text { thermal insulator by making } \\
\text { two cylinders with } 3 \text { cm } \\
\text { diameter different. } \\
\text { 3. Prepare the similar blanket as } \\
\text { the container cover. } \\
\text { 4. Put the container inside the } \\
\text { insulation blanket. } \\
\text { 5. Insert the insulation materials } \\
\text { between two cylinder } \\
\text { cartoon. }\end{array}$ & $\begin{array}{l}\text { How is the } \\
\text { best way to } \\
\text { design the } \\
\text { vacuum flask? } \\
\text { How to keep } \\
\text { the } \\
\text { temperature } \\
\text { of hot coffee } \\
\text { in a glass? }\end{array}$ & 90 mins \\
\hline
\end{tabular}




\begin{tabular}{|c|c|c|c|c|c|c|c|}
\hline No & Experiments & $\begin{array}{c}\text { Student's } \\
\text { Competences }\end{array}$ & Assumptions & $\begin{array}{c}\text { NOS } \\
\text { Objectives }\end{array}$ & Details & $\begin{array}{c}\text { Related Daily } \\
\text { Problems }\end{array}$ & \begin{tabular}{|c} 
Allocated \\
Time
\end{tabular} \\
\hline & & & & & $\begin{array}{l}\text { 6. Fill the } 500 \mathrm{ml} \text { water into the } \\
\text { container } \\
\text { 7. Install the digital } \\
\text { thermometer in the } \\
\text { container. } \\
\text { 8. Cover the container with the } \\
\text { blanket cover. } \\
\text { 9. Put it on the water heater. } \\
\text { 10. Plug in the watt meter into } \\
\text { the electric socket. } \\
\text { 11. Plug in the heater-plug into } \\
\text { the watt meter. } \\
\text { 12. Turn on the watt meter } \\
\text { 13. Record the initial } \\
\text { temperature of water in the } \\
\text { container. } \\
\text { 14. Set the watt meter to view } \\
\text { the energy used by an electric } \\
\text { heater. } \\
\text { 15. Monitor the energy used by } \\
\text { an electric heater to be set as } \\
\text { heat given. At the same time, } \\
\text { monitor the increase of } \\
\text { water temperature inside the } \\
\text { container to be processed as } \\
\text { heat received. }\end{array}$ & & \\
\hline
\end{tabular}

Table 2. The complete experiment designs on heat and temperature supporting the student's nature of science

\section{1. $4^{\text {th }}$ Experiment: Building the digital thermometer using an Arduino-based LM35 Temperature sensor}

Arduino is an open source and single microprocessor single-board designed to ease the users constructing the electronics. The hardware has Atmel AVR processor and unique software based on $\mathrm{C}++$ programming language. Arduino Uni board is the common microcontroller used by beginners. The last version of the Arduino Uno R3 (Revision 3) applies ATMEGA328 as a microcontroller. It has 14 digital I/O pins and 6 analog input pins. Figure 2 shows the part of Arduino R3.

To construct the project, the analog LM35 temperature sensor is used. This sensor is able to measure the temperature range from $-55^{\circ} \mathrm{C}$ to $150^{\circ} \mathrm{C}$, with the temperature resolution of $0.5^{\circ} \mathrm{C}$, accuracy $\pm 1.5^{\circ} \mathrm{C}$. The change of $10 \mathrm{mV}$ potential difference will alter the linear temperature by $1^{\circ} \mathrm{C}$. Figure 3 shows the graph of current and potential difference due to the temperature change.

The solderless protoboard is used to arrange the electrical circuit. The electronic devices are pinned into the protoboard holes. Student's understanding of the protoboard pattern is required to construct the right electrical circuit. Figure 4 shows the pattern of protoboard in rows and columns.

In this project, students can build a temperature sensor circuit based on an LM35 sensor and integrate it to an LCD. Therefore, the temperature can be read on the LCD. They have to connect the circuit to mimics a more like electronic product where students see it on the market. To construct this circuit, they need 3 main components. This project will use an LM35 temperature sensor. An HD44780 $16 \times 2$ LCD display is needed to read the temperature. Moreover, the Arduino Uno as a microcontroller is required to interpret the readout of LM35 sensor IC and then display it on the LCD. Of course, students need to hook up wires to wire all the connections.

The circuit which we will build to interface a temperature sensor to an LCD for LCD readout is shown in Figure 5. 


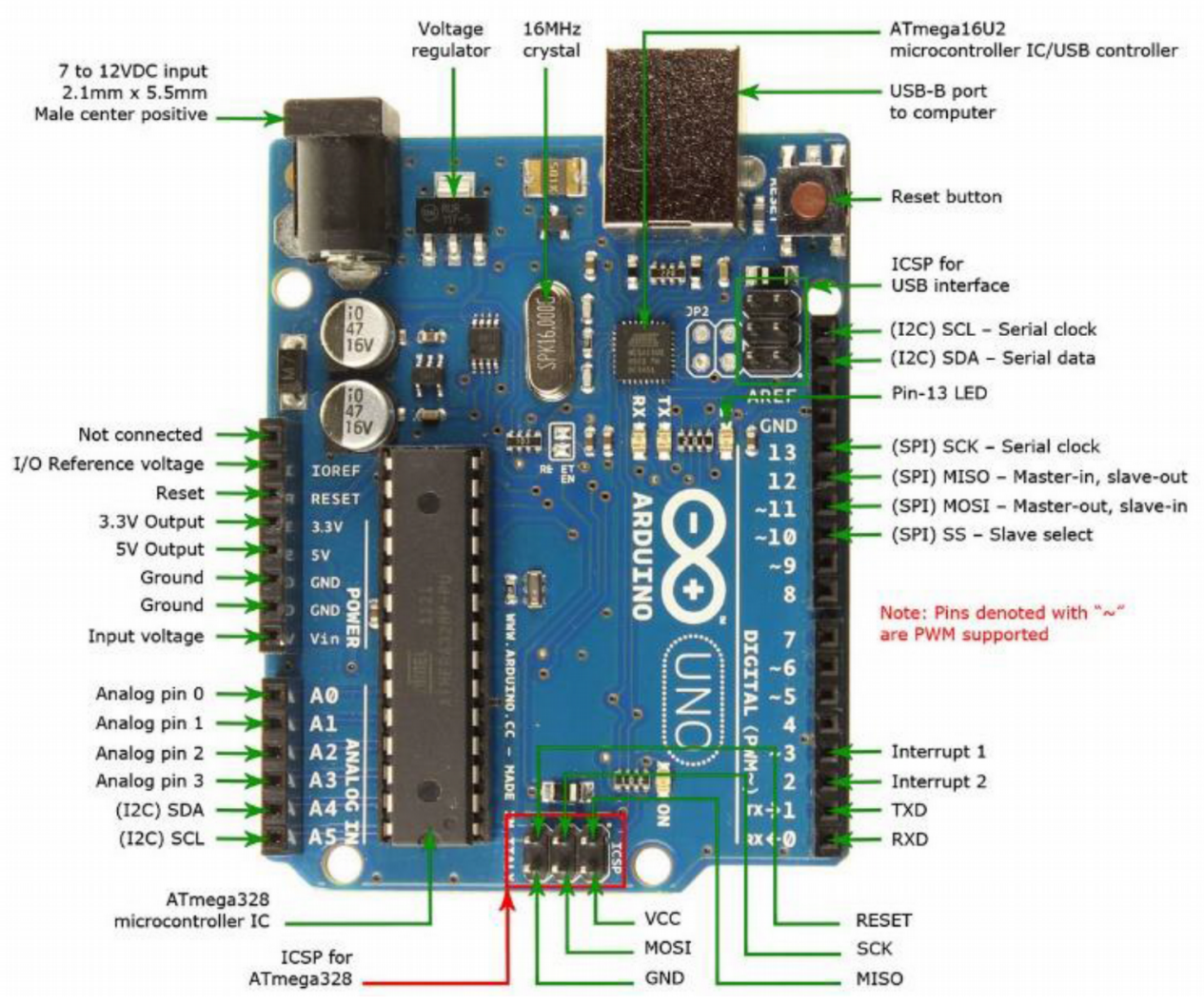

Figure 2. Part of Arduino Uno R3
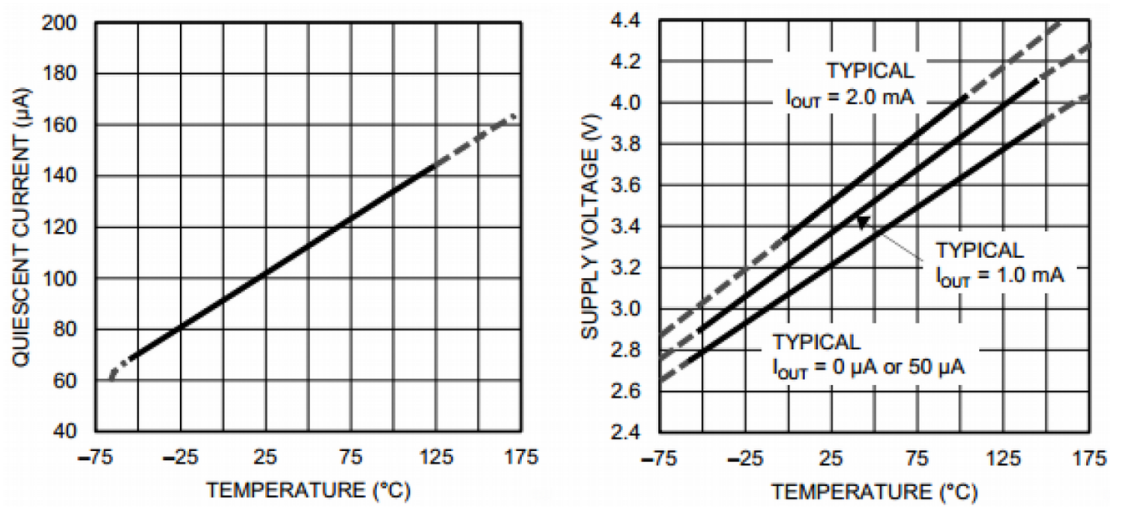

Figure 3. The current and potential difference change due to the temperature difference

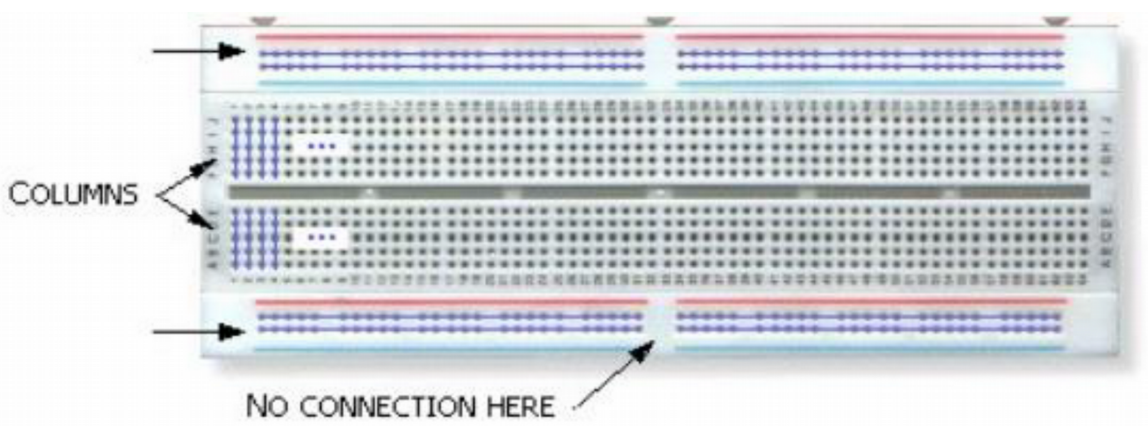

Figure 4. The pattern of protoboard in rows and columns

These stages discuss how to connect the LCD to Arduino. (a) The LCD pin GND must be connected to the Arduino pin GND. (b) The LCD pin +5V must be connected to the Arduino pin 5V. (c) The LCD pin Contrast is not connected to the Arduino pin. (d) The LCD pin RS (Register Select Pin) must be connected to the Arduino pin 12. (e) The LCD pin R/W (Read/Write Pin) must be connected to the 
Arduino pin GND. (f) The LCD pin E (Clock Enable Pin) must be connected to the Arduino pin 11. (g) The LCD pins D0-D4 are not connected to the Arduino pin. (h) The LCD pin D4 must be connected to the Arduino pin 5. (i) The LCD pin D5 must be connected to the Arduino pin 4. (j) The LCD pin D6 must be connected to the Arduino pin 3. (k) The LCD pin D7 must be connected to the Arduino pin 2. (l) The LCD pin Anode (for backlight) must be connected to the Arduino pin 5V. (m) The LCD pin Cathode (for backlight) must be connected to the Arduino pin GND.

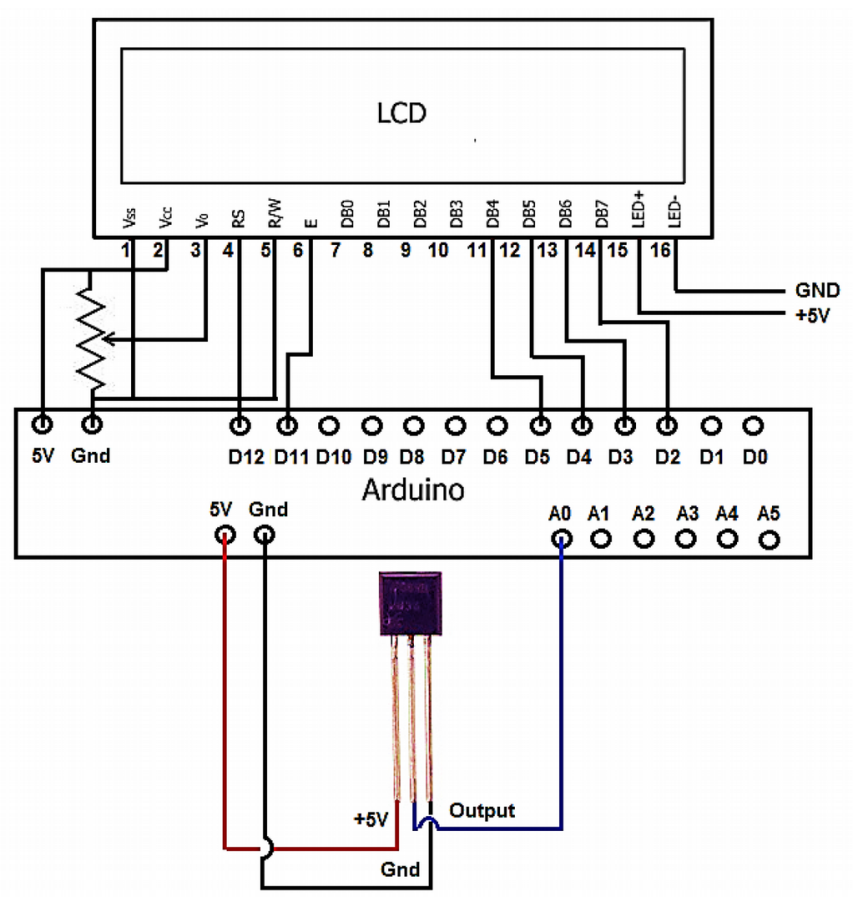

Figure 5. The schematic circuit to construct the hands-on digital thermometer

These stages discuss how to connect the LM35 sensor to Arduino. Follow these stages to construct the successful project. (a) The LM35 pin $+5 \mathrm{~V}$ must be connected to the Arduino pin 5V. (b) The LM35 pin Output must be connected to the Arduino pin A0. (c) The LM35 pin GND must be connected to the Arduino pin GND.

The code is required to interpret the LM35 sensor signal. The first line of code includes the LiquidCrystal library. With this library, we can utilize functions (such as lcd.print) that make coding this project much easier. The fifth block of code is our actual loop for our circuit. In this block, we read the analog voltage from the temperature sensor IC from the output pin. We convert this voltage into temperature Fahrenheit. We then print out this temperature to the lcd using the lcd.print function. We then take a 5-second delay. This way, the temperature IC reads and updates the temperature every 5 seconds.

\section{Code}

\#include $<$ LiquidCrystal.h $>$

int outputpin= 0 ;

const int numRows $=4$;

const int numCols $=20$;

//initialize the library with the numbers of the interface pins

LiquidCrystal $\operatorname{lcd}(12,11,5,4,3,2)$;

void setup0 


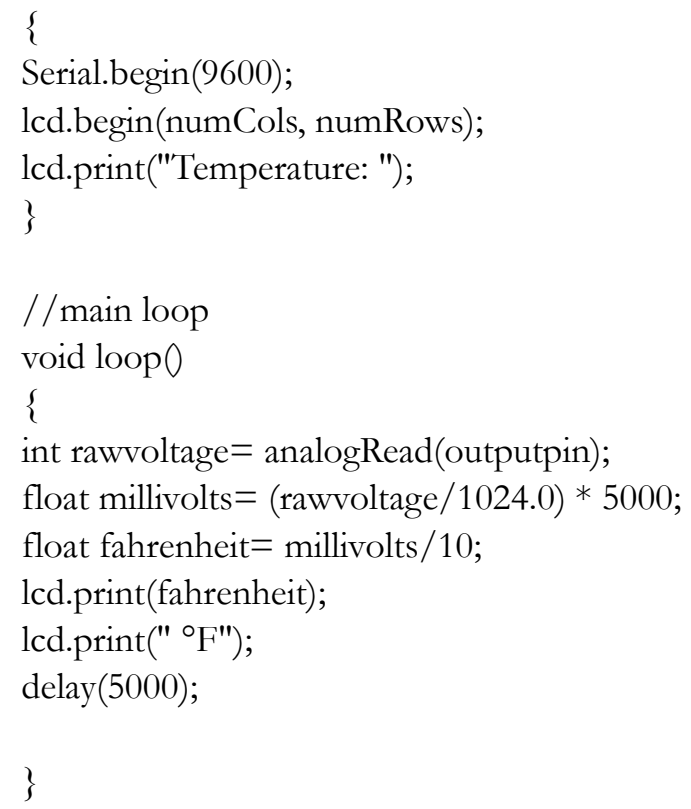

\section{Result and Discussion}

When we consider the learning media used to support student's conception of the nature of science, the discussion can be divided into two parts. Firstly, how the nature of science is the fundamental aspect of building scientific knowledge such as explaining scientific phenomena, designing experiment, evaluating the results and interpreting data based on scientific evidence. Second, how the implementation evaluates students' conception of the nature of science by providing problem-solving laboratory activities. The following discussion is examples of media developed in this research.
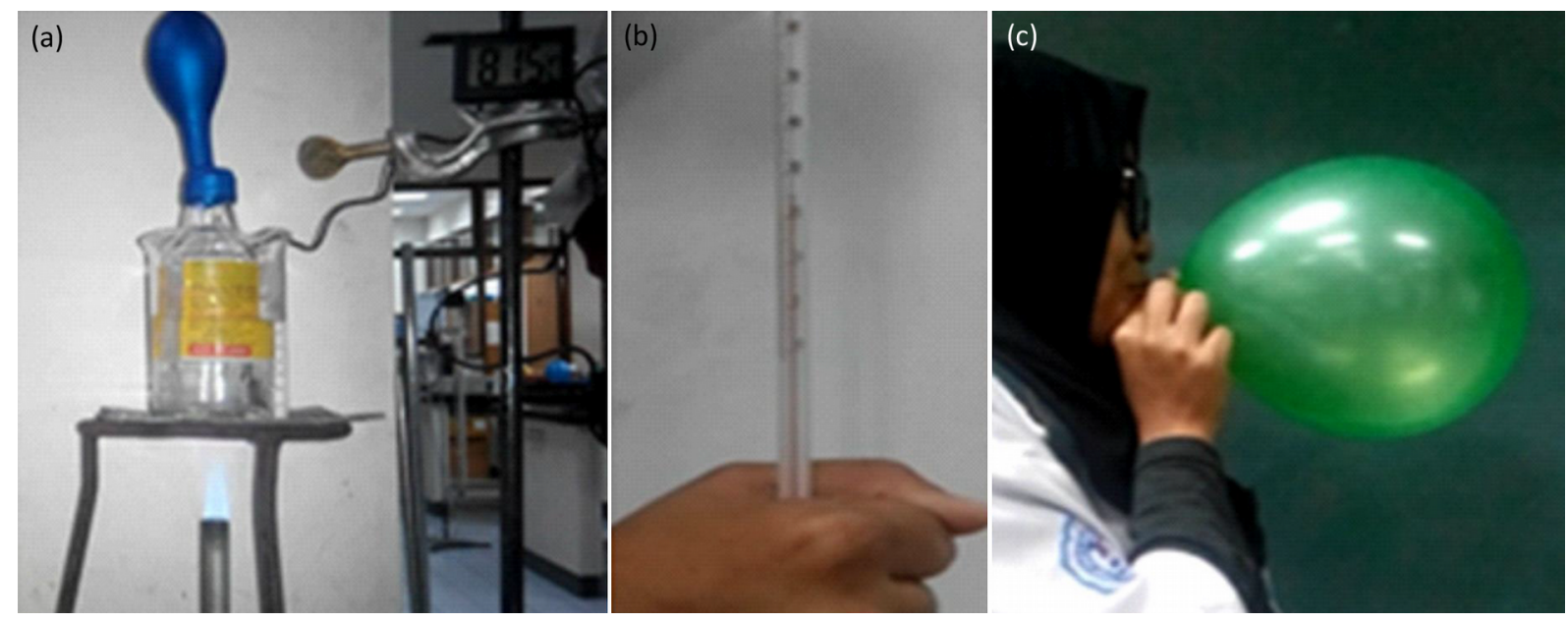

Figure 6. Demonstration activity to construct the concept of thermal expansion and temperature. (a) a balloon is being heated, (b) thermometer is held by a hand, (c) a balloon is being blown

Figure 6 demonstrates the first experiment activities to explain natural phenomena. By performing the demonstration, a teacher gives questions and answers to explain the definition of temperature and thermal expansion. Thermal expansion happens due to the changes in an object's volume when heat is being received. It is noticed that the process is reversible. Sometimes, students might be confused by this concept. The teacher can compare the phenomenon towards the balloon's volume expansion as a teacher blows the balloon. The inflation will change the balloon's volume, but it is not caused by heat. When a balloon-equipped bottle is being heated, the air inside the balloon will be expanded causing volume expansion. The expansion shows a reversible process due to temperature changes. A thermometer can be 
used to test the equipment's temperature. This is a good example to show the volume expansion application. This phenomenon is important to be discussed with students in order to construct the concept of thermal expansion. The interesting finding shows that some Indonesian students still believe that when a sink cracker "Krupuk" in a kettle is being heated, it results in the volume changes as well as the volume expansion. Students must understand the physical terms of thermal expansion in this case as a reversible process. When there is no heat received and transferred from or to the system, the thermal equilibrium will be achieved. The thermometer used in this experiment will show the temperature of the tested system.

Some experiment trials have been developed. The experiments tend to show good results. The demonstration activities can be repeated showing the same result. Therefore, the activity can be demonstrated to explain the nature of thermal expansion. To improve the quality of the result, students have to plan and evaluate the scientific experiment. In the first plan, students plan to design the thermal expansion experiment by investigation the materials used for making a mercury-in-glass thermometer. However, the materials are dangerous to handle so that they seek another material that can be used as a thermometer. The linear expansion of a liquid must be proportional to the linear increase in temperature. Consequently, it is found that water or alcohol might be useful for this experiment. On the other hand, they find that water has a unique character due to its maximum density at $4^{\circ} \mathrm{C}$. Alternatively, they can use alcohol as a good material for the thermometer purpose. The other challenges must be considered so that they are able to make a hand-made thermometer. It can be seen that at the bottom of the thermometer, there is a bigger volume of thermometer chamber receiving the heat sources where the thinnest glass is constructed. Therefore, how the heat received by thermometer must be imitated by a hand-made thermometer. The activities relate to the context domain of PISA 2015 about making an equipment.

Students construct the hand-made thermometer using a cylinder glass covered by a one-hole rubber bung. A small cylinder is penetrated through this hole and it is filled using a colored alcohol. This hand-made thermometer is placed under water because the water is easy to contact the thermometer during being heated. The student's design is shown in Figure 7.
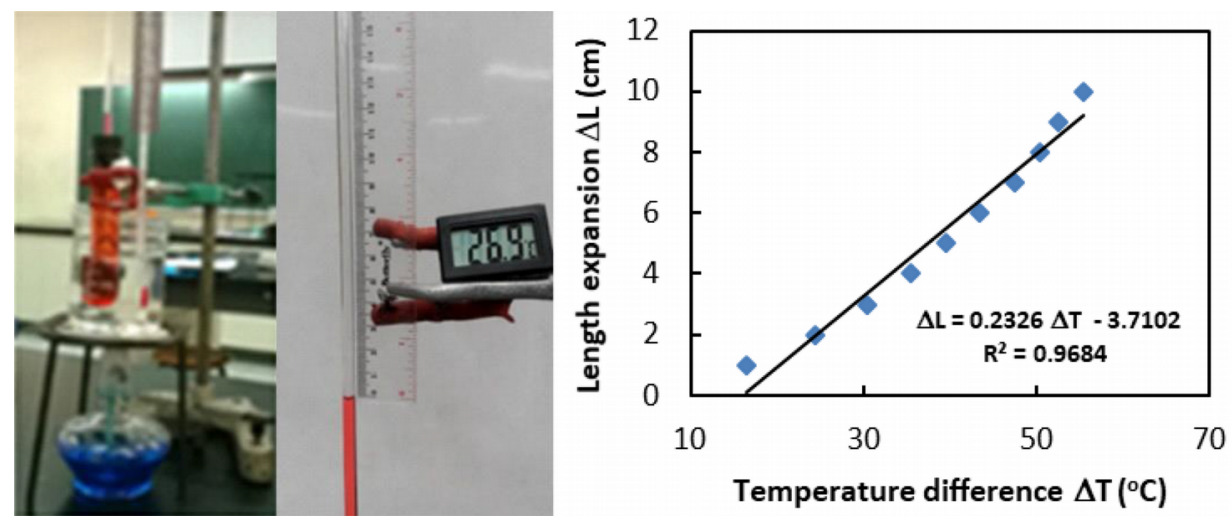

Figure 7. Second experiment design to construct the concept of linear thermal expansion as the working principle of the thermometer

To ease data collection and show more accurate data, the measurement is performed using a digital thermometer while the length expansion of alcohol is recorded using a video recorder. This strategy is very helpful to investigate temperature change during volume expansion. The graph is also taken from data of volume expansion in liquids. It can be concluded that this experiment can facilitate students to test the prediction of the nature of thermal expansion. Students propose the hypotheses that the graph is predicted as the linear expansion. This property is important to set the good quality of thermometer. The assumptions are addressed to this result, the increase of temperature of alcohol inside the test tube should be the same as the increase of temperature in water detected by a digital thermometer. If the fact does not 
follow the assumption, the result tends to show the small error. As a result, the alcohol linear expansion tends to show the proportional function to the $96.84 \%$ linear expansion with the function of $\Delta \mathrm{L}=0.2326$ $\Delta \mathrm{L}-0.37102$ and $3.16 \%$ error. The error can be found due to the difficulties of placing the digital thermometer in the water. It is previously assumed that the temperature indicated by the thermometer is the same as the temperature inside the alcohol-cylinder thermometer. Furthermore, the effect of heat received by the glass is also neglected in this investigation. The hand-made thermometer calibration can be conducted after obtaining this data. Students are able to make lines in this small cylinder to indicate certain temperatures. Finally, the hand-made thermometer can be used in another case for exercising the student's creativity as a goal of the nature of science. Students understand the basic principle of the thermometer, plan the thermal expansion experiment, and make a product as required in a conception on the nature of science.

This problem is improved by presenting problem-solving laboratory activities. The investigation relates to the context of finding new material. In this case, students are asked to elaborate solutions by considering alcohol: water concentration. Students think that the alcohol concentration may affect the linear expansion. It is a very interesting activity to provide engineering activities in high school. Students make a hypothesis that the thermal expansion coefficient will change due to fluid concentration. They elaborate on the alcohol concentration by diluting it into the water. As a result, the laboratory test shows the result as expected. They found that the difference in alcohol concentration $(90 \%, 70 \%$, and $30 \%)$ affects the expansion coefficient as seen in Figure 8.

The result can be found that the decrease of the alcohol concentration, the decrease of the length expansion response due to the increase of temperature difference. The data of volume thermal coefficient of alcohol is about $1120 \times 10^{-6} / \mathrm{K}$, while the water is about $207 \times 10^{-6} / \mathrm{K}\left(20^{\circ} \mathrm{C}\right), 303 \times 10^{-6} / \mathrm{K}\left(30^{\circ} \mathrm{C}\right)$, and $385 \times 10^{-6} / \mathrm{K}\left(40^{\circ} \mathrm{C}\right)$. The theoretical prediction shows that the combination of alcohol and water will decrease the thermal coefficient of the solution which is less than alcohols. The prediction is confirmed by the finding as seen in Figure 8. Students are able to model this result so that they are able to compose the value of volume thermal coefficient of the solution by considering the concentration of alcohol and water. The value will vary between $207 \times 10^{-6} / \mathrm{K}$ and $1120 \times 10^{-6} / \mathrm{K}$ although the value is not exact due to the non-proportional response of water towards the temperature change.

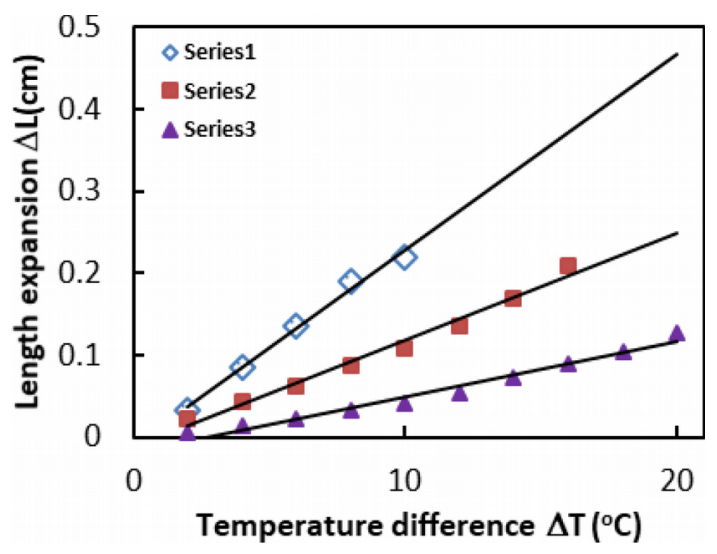

Figure 8. Third experiment design: the effect of alcohol concentration towards linear thermal expansion. Series 1 ,

2 , and 3 relate to alcohol concentration $90 \%, 70 \%$, and $30 \%(\mathrm{v} / \mathrm{v})$, respectively. The contextual problem is given

to find materials suitable for a new thermometer

Figure 9 presents the fourth equipment design to exercise problem-solving laboratory activities. Students design scientific equipment based on their interest. In Indonesia, the Fahrenheit or Reaumur thermometer may not be found in the market so that students are requested to design the equipment by themselves 
after learning the expansion concept. The scales are constructed using a bar thermometer. Students set the lowest level of freezing water point at $0^{\circ} \mathrm{C}$, which is equal to the $0^{\circ} \mathrm{R}$ and $32^{\circ} \mathrm{F}$, and they also set the highest level of boiling water point at $100^{\circ} \mathrm{C}$, which is equal to the $80^{\circ} \mathrm{R}$ and $212^{\circ} \mathrm{F}$. The length of bar thermometer is plotted and designed using a computer program so that the lines on the certain scale for each $10^{\circ}$ increments can be set accurately.
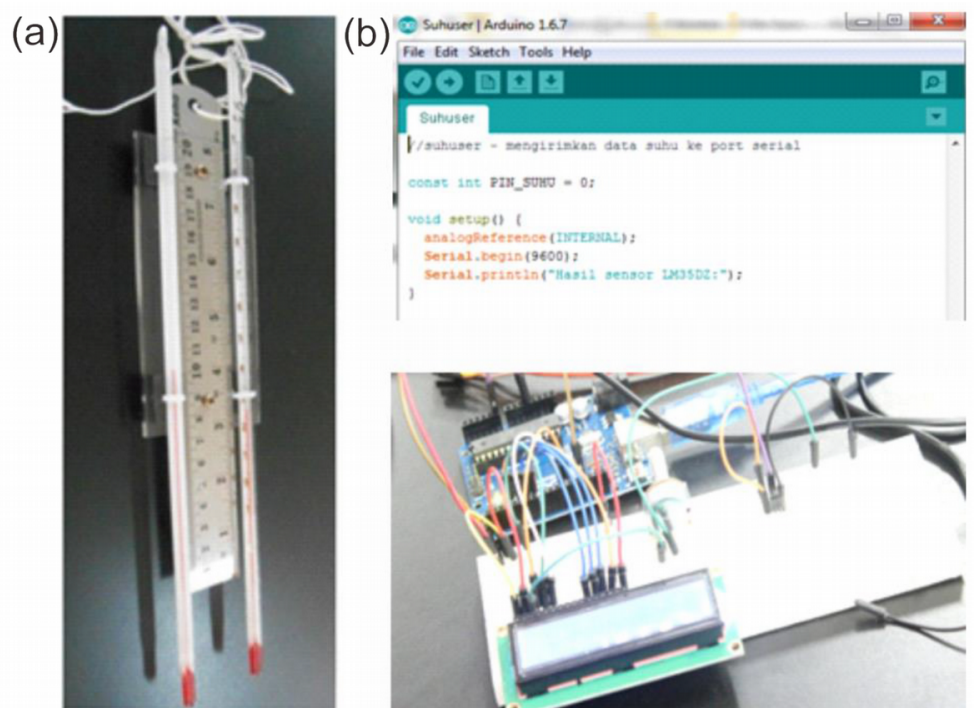

Figure 9. Fourth Equipment design to exercise problem-solving laboratory activities on making (a) an analog and (b) a digital thermometer. A model of Fahrenheit or Reaumur thermometer can be provided

The scientific activity based on students' interest can be developed in this work. During constructing the analog Fahrenheit or Reaumur thermometer, the bar and the scaled thermometers are installed in parallel as seen in Figure 9(a). A ruler is required to set the level of material expansion at least on two conditions: at a freezing and a boiling point of water in 1 atmospheric pressure. Students must know the scaled standard of Fahrenheit and Reaumur previously. A transparent tape can be attached on the bar thermometer so that the scale can be indicated. The scale must be written clearly. Furthermore, they can also make their own scale by creating their own scale at a freezing and a boiling point of water in 1 atmospheric pressure. These inquiry activities are required so that they are able to collect meaningful data, organize, and analyze data accurately and precisely.

By using the technology during investigations of temperature, students can also construct the temperature sensor system based on microcontroller and $\mathrm{C}++$ programming language. To make a digital thermometer based on a microcontroller, students must learn the electronic circuit firstly. They use the Arduino program to make this equipment based on the LM35 temperature sensor. In this sensor, LM35 consists of three legs. one as a negative terminal, one as a positive terminal plugged between $3.3-5.0 \mathrm{~V}$, and one as a sensor terminal. Students use a voltmeter to investigate the effect of environmental temperature change on the potential difference change in the LM35 sensor. Students record the data of the potential difference profile to be analyzed based on the environment temperature change. They found that the increase of temperature by $1^{\circ} \mathrm{C}$ will increase the potential difference by $10 \mathrm{mV}$. Finally, they obtain the calibration data, where the potential difference must be divided by 9.31 to fit the digital thermometer data. The work must be improved by showing the data digitally using LCD display $8 \times 2$. Therefore, they write the code in the Arduino program and show it on the LCD display.

To investigate the linear temperature expansion coefficient of some metals, some high schools still utilize the old pyrometer with levers using Musschenbroek apparatus. However, this apparatus can only differentiate the length of expansion coefficients of materials qualitatively. To improve the apparatus 
quality, we have redesigned the equipment by connecting the rod edge as materials being heated to the depth rod of digital vernier caliper. Figure 10 shows the experimental design to construct the concept of the linear temperature expansion coefficient of some metals. Therefore, the measurement can be conducted more accurate. The digital thermocouple is also equipped with a rod surface in order to monitor the temperature change during heating applied to the rod. Both temperature change and rod expansion are recorded by the video recorder. This activity can be introduced to improve their skills in improving the method to take a data. Finally, they are able to improve the accuracy of measurement and decrease the error scientifically.

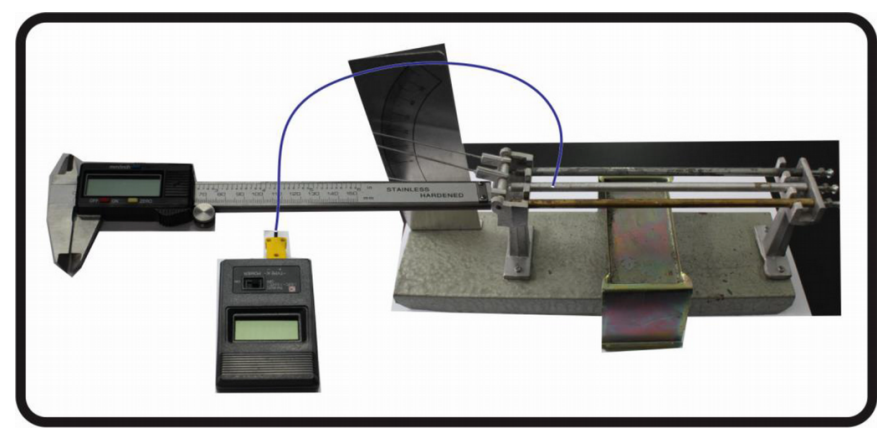

Figure 10. Fifth experiment design to construct the concept of the linear temperature expansion coefficient of some metals

To use this equipment, the metal rod $(30 \mathrm{~cm}$ length, $6.5 \mathrm{~mm}$ diameter) is placed on the Musschenbroek apparatus, students use materials from copper, zinc, brass, steel, and stainless steel for this experiment. The screw in the right edge is turned so that the needle in the left edge indicate the 0 value. The electric heater is touched on the metal rod surface while the thermocouple sensor is touched on the edge of metal rode. The digital vernier caliper is turned on and calibrated to zero before the rod is being heated. The vernier caliper position is to hold using a stand so that the depth rod of digital vernier caliper is firmly attached to the edge of the heated metal rod. The heater is turned on and the displays of the digital vernier caliper and the thermocouple-thermometer are recorded using a video recorder. Table 3 tabulates experiment result. It is confirmed that this experiment can be performed well by students. The percentages of error are varied between $1.93-5.93 \%$. Zinc shows the best result having the smallest error while steel shows the biggest difference between the expected value of the error at $5.93 \%$. However, the errors are presented in the tolerable values to perform a good experiment for students in high schools.

\begin{tabular}{|c|c|c|c|r|}
\hline No & Materials & $\begin{array}{c}\text { Linear Temperature } \\
\text { Expansion Coefficient } \\
\boldsymbol{\alpha}_{\text {measured }}\left(\boldsymbol{K}^{-1}\right)\end{array}$ & $\begin{array}{c}\text { Reference } \\
\boldsymbol{\alpha}_{\text {standard }}\left(\boldsymbol{K}^{-1}\right)\end{array}$ & Percentage Error (\%) \\
\hline 1 & Copper & $1.74 \times 10^{-5}$ & $1.70 \times 10^{-5}$ & 2.29 \\
\hline 2 & Zinc & $2.94 \times 10^{-5}$ & $3.00 \times 10^{-5}$ & 3.93 \\
\hline 3 & Brass & $1.96 \times 10^{-5}$ & $1.90 \times 10^{-5}$ & 5.93 \\
\hline 4 & Steel & $1.11 \times 10^{-5}$ & $1.18 \times 10^{-5}$ & 2.08 \\
\hline 5 & Stainless Steel & $1.77 \times 10^{-5}$ & $1.73 \times 10^{-5}$ & \\
\hline
\end{tabular}

Table 3. Experiment result of linear temperature expansion coefficient based on equipment design in Figure 10

In other cases, we have developed a new model of the bimetallic strip to be made by students easily as seen in Figure 11. Basically, making a common bimetallic strip is difficult to be handled by high school students due to the difficulty of attaching two different materials. The metals must be welded at high temperature. It spends a high cost and it is dangerous for untrained students. Whereas, it is necessary to 
make a bimetal model so that students will understand the real phenomenon of expansion in the bimetal strip. In a daily life, this equipment is commonly used as a thermostat, which is applied to ironing. To simplify the project, the equipment is made by connecting two different solid materials with different linear expansion coefficient. The process must be easy to be followed by students. Therefore, we propose the unique idea of utilizing a piece of paper and aluminum sheet to be patched using glue. The project has been conducted successfully. Because paper made of cellulose $\left(130 \times 10^{-6} \mathrm{~K}^{-1}\right)$ has a greater thermal expansion coefficient than aluminum $\left(24 \times 10^{-6} \mathrm{~K}^{-1}\right)$. The hotter condition of this bimetal will expand the paper more and its greater length put it on the outside of the curve.
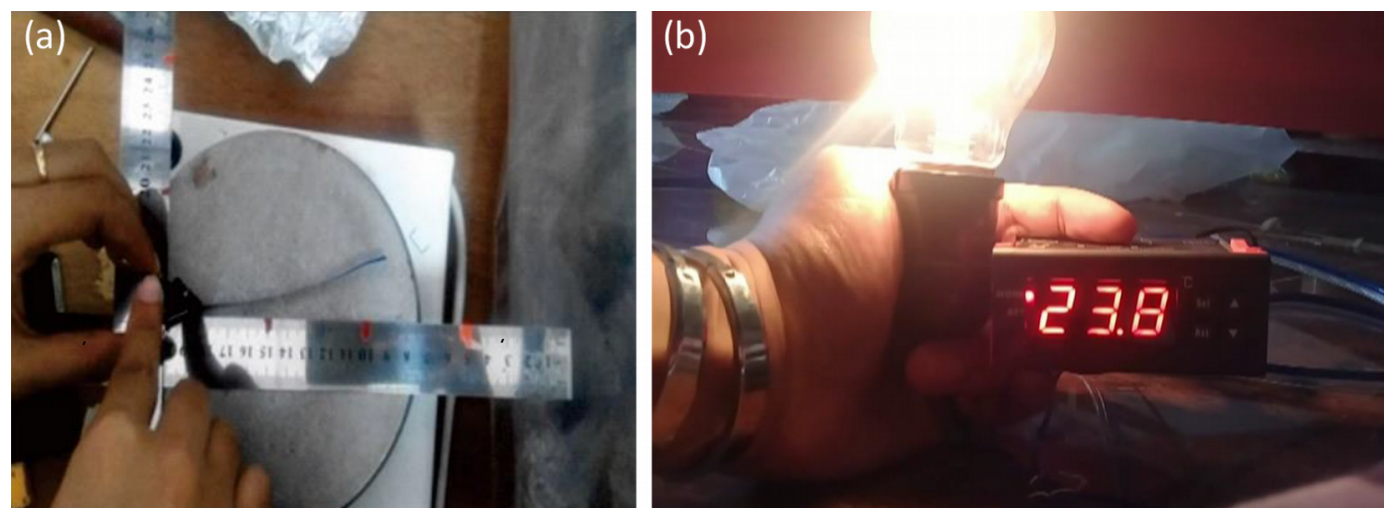

Figure 11. Experiment designs of (a) bimetal strip model and (b) thermostat-equipped egg incubator

For the industrial purposes, the utilization of bimetal is also applied to the egg incubator electronically. In a thermostat, there is a bimetal that actually moves as the temperature changes and this movement causes the electrical connection to open or close. As they expand and contract differently, they move closer together or farther apart. This is what causes the electrical connection to open or close. In this work, a digital thermostat will include a thermometer as part of the device so the students can set the incubator thermostat to the desired set-point and then just walk away. A room $(40 \times 30 \times 30 \mathrm{~cm})$ made of plastics can be set to construct the egg incubator. In this design, the environmental temperatures can be maintained and controlled by an electrical thermostat. Heat is given by a lamp placed in the container while eggs are placed in the same container. The thermostat will monitor heat produced by the lamp, and the lamp will turn on and turn off based on the temperature set by ourselves. Although the results should be further optimized, students can really apply the concept of bimetal in manufacturing egg incubator.

As the PISA 2015 deliver the simulation of heat transfer, the students are asked to investigate the conditions that will produce the most effective cooling effects $\left(4^{\circ} \mathrm{C}\right)$ for keeping food fresh in the Zeer pot by altering the thickness of the sand layer and the moisture conditions. The same as PISA's study, in this work, the students will be challenged to set the effective set in order to maintain temperature $\left(75^{\circ} \mathrm{C}\right)$ of hot coffee or milk tea. Figure 12 shows the experimental design to investigate the effect of thermal insulation. As the understanding of Black's principle, to identify the effect of heat given towards temperature change of an object including its phase, this phenomenon can be demonstrated easily. We can use the water heaters available in markets. The water heater should be equipped with a watt meter plug to provide information about the amount of constant electrical energy supplied (heat is given) to the system although there is energy loss released to the environment. By using the watt meter as seen in Figure 12, the heat supplied to the system can be monitored in real time. The thermometer is also contacted to the water in this container. The temperature increment can be seen by turning on and improve the power of this machine supplying the heat to the system. By applying Black's principle stating that "By mixing the two substances, the amount of heat that is released substances higher temperature equal to the number of heat received by a lower temperature substance". This experiment uses a calorimeter to investigate temperature change. The students are asked to develop the project in order to investigate the efficiency of heat received by the system by inserting thermal insulation materials such as styrofoam $\left(1.3 \mathrm{J.g}^{-1} \mathrm{~K}^{-1}\right)$, 
sawdust $\left(1.2 \mathrm{Jgg}^{-1} \mathrm{~K}^{-1}\right)$ and dacron $\left(1.1 \mathrm{J.g}^{-1} \mathrm{~K}^{-1}\right)$. The engineering process is also included in this work. Students will be able to design the appropriate thermal insulation materials based on its type or thermal insulation thickness. The result implied that specific heat capacity plays a significant role in insulating the heat and maintain the temperature of hot coffee.
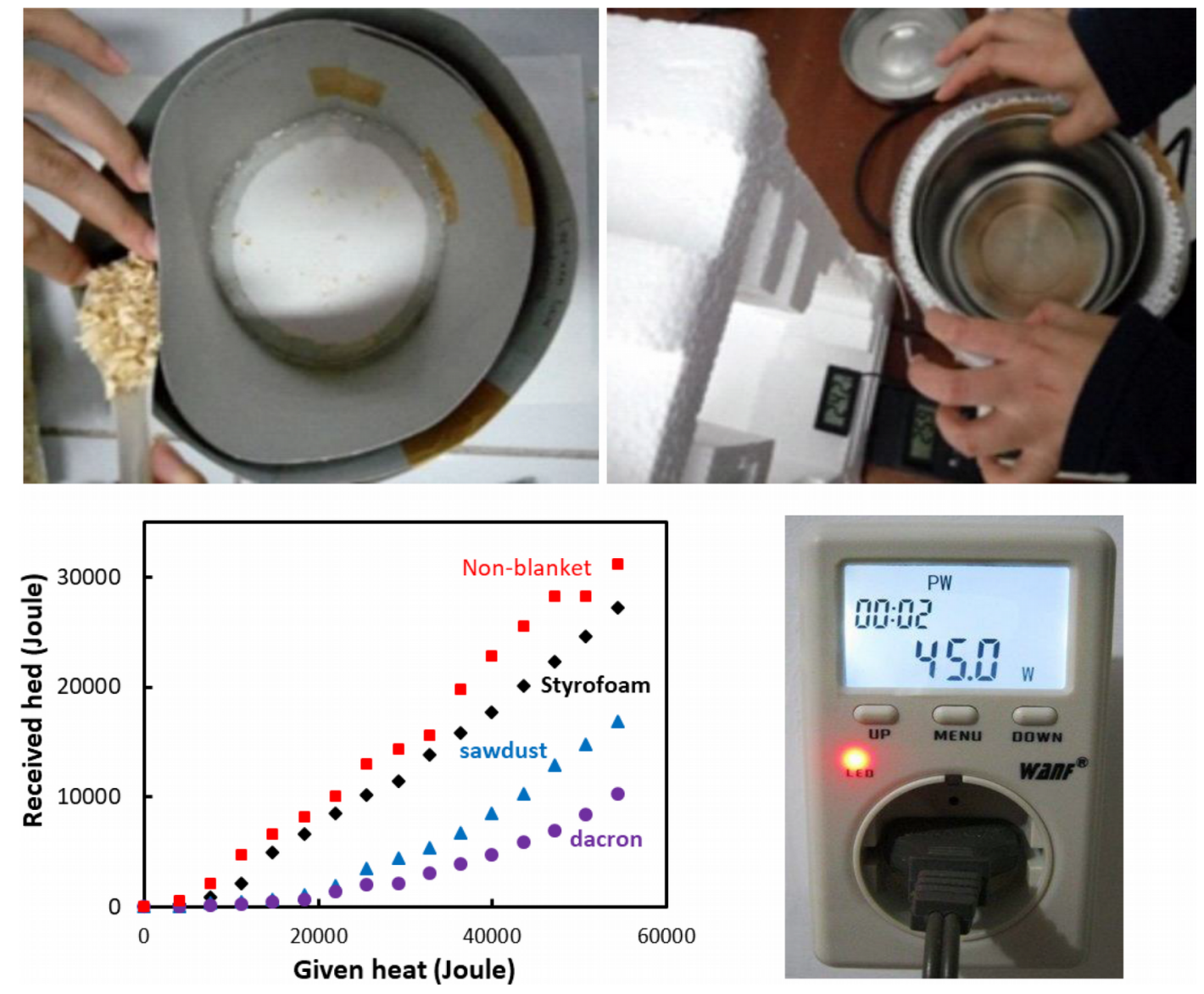

Figure 12. Experiment design for investigating the effect of thermal insulation

\section{Conclusion}

Science knowledge and contextual problems on Heat and Temperature topics have been constructed successfully. The heat and temperature-based learning media are applied to support student's conception of the nature of science. The two type of media has been proposed to construct science knowledge and to serve problem-solving laboratory. To construct science knowledge, we demonstrate the activity to construct the concept of thermal expansion and temperature. The experiment is designed to construct the concept of linear thermal expansion as the working principle of the thermometer as well as the linear temperature expansion coefficient of some metals. To serve problem-solving laboratory, we investigate the effect of alcohol concentration towards linear thermal expansion as an alternative solution of thermometer materials. Students are challenged to make an analog and a digital thermometer. The bimetal strip is made to understand the working principle of the thermostat as the equipment to maintain the environment temperature in the egg incubator. The thermal insulation materials are investigated to understand the working principle of a vacuum flask. This experiment designs on heat and temperature are important to support students' conception of the nature of science.

\section{Declaration of Conflicting Interests}

The authors declared no potential conflicts of interest with respect to the research, authorship, and/or publication of this article. 


\section{Funding}

We acknowledge DIKTI for the financial supports of Hibah Penelitian Unggulan Perguruan Tinggi 2017.

\section{References}

Abd-El-Khalick, F., \& Lederman, N.G. (2000). Improving science teachers' conceptions of nature of science: a critical review of the literature. International journal of science education, 22(7), 665-701. https://doi.org/10.1080/09500690050044044

American Association for the Advancement of Science - AAAS (1990). Science for all Americans. New York: Oxford University Press.

Art, H. (2003). Physics literacy, energy and the environment. Physics Education, 38(2), 109.

https://doi.org/10.1088/0031-9120/38/2/301

Clough, G.W. (2011). Increasing scientific literacy: A shared responsibility. Smithsonian Institution.

DeBoer, G.E. (2000). Scientific literacy: Another look at its historical and contemporary meanings and its relationship to science education reform. Journal of Research in Science Teaching: The Official Journal of the National Association for Research in Science Teaching, 37(6), 582-601. https://doi.org/10.1002/10982736(200008)37:6<582::AID-TEA5>3.0.CO;2-L

Dewey, J. (1904). The relation of theory to practice in education. Chicago: University of Chicago Press.

Dick, W. (1996). The Dick and Carey model: Will it survive the decade? Educational Technology Research and Development, 44(3), 55-63. https://doi.org/10.1007/BF02300425

Duschl, R.A. (1987). Improving science teacher education programs through inclusion of history and philosophy of science. In Barufaldi, J.P. (Ed.), Improving Preservice/Inservice Science Teacher Education: Future Perspectives. The 1987 AETS Yearbook. Association for the Education of Teachers.

Eisenkraft, A. (2010). Millikan Lecture 2009: Physics for all: From special needs to Olympiads. American Journal of Physics, 78(4), 328-337. https://doi.org/10.1119/1.3293130

Karim, S., Prima, E.C., Utari, S., Saepuzaman, D., \& Nugaha, M.G. (2017). Recostructing the Physics Teaching Didactic based on Marzano's Learning Dimension on Training the Scientific Literacies. Journal of Physics: Conference Series, 812(1). https://doi.org/10.1088/1742-6596/812/1/012102

Kevin, C. (2000). Teaching about heat and temperature. Physics Education, 35(2), 101.

https://doi.org/10.1088/0031-9120/35/2/304

Lederman, N.G., Abd-El-Khalick, F., Bell, R.L., \& Schwartz, R.S. (2002). Views of nature of science questionnaire: Toward valid and meaningful assessment of learners' conceptions of nature of science. Journal of research in science teaching, 39(6), 497-521. https://doi.org/10.1002/tea.10034

Lederman, N.G., Lederman, J.S., \& Antink, A. (2013). Nature of science and scientific inquiry as contexts for the learning of science and achievement of scientific literacy. International Journal of Education in Mathematics, Science and Technology, 1(3).

Marzano, R.J., Pickering, D., \& McTighe, J. (1993). Assessing Student Outcomes: Performance Assessment Using the Dimensions of Learning Model. Virginia: ERIC.

McComas, W.F., Clough, M.P., \& Almazroa, H. (1998). The role and character of the nature of science in science education. The nature of science in science education (3-39). Springer, Dordrecht.

Miller, J.D. (1983). Scientific literacy: A conceptual and empirical review. Daedalus, 29-48.

National Research Council (1996). National science education standards. National Academies Press. 
Nicola, P., Claudio, F., \& Onofrio-Rosario, B. (2014). Open inquiry-based learning experiences: a case study in the context of energy exchange by thermal radiation. European Journal of Physics, 35(1).

Niess, M.L. (2005). Preparing teachers to teach science and mathematics with technology: Developing a technology pedagogical content knowledge. Teaching and teacher education, 21(5), 509-523

Organisation for Economic Co-operation and Development, \& PISA (2013). Excellence Through Equity: Giving Every Student the Chance to Succeed. Paris: OECD Publishing.

PISA (2015). PIS A: Results in Focus. Organisation for Economic Co-operation and Development (OECD).

Prima, E.C., Karim, S., Utari, S., Ramdani, R., Putri, E.R.R., \& Darmawati, S.M. (2017). Heat Transfer Lab Kit using Temperature Sensor based ArduinoTM for Educational Purpose. Procedia engineering, 170, 536-540. https://doi.org/10.1016/j.proeng.2017.03.085

Rodríguez-García, A., Astrain-Ulibarrena, D., Martínez-Echeverri, Á., Aranguren-Garacochea, P., \& Pérez-Artieda, G. (2013). Development and Experimental Validation of a Thermoelectric Test Bench for Laboratory Lessons. Journal of Technology and Science Education, 3(3), 113-121.

Shirish, P., Saurabhee, H., Madhura, N., Savita, L., \& Hemachandra, P. (2015). Understanding thermal equilibrium through activities. Physics Education, 50(2), 146. https://doi.org/10.1088/0031-9120/50/2/146

Wenning, C.J. (2006). Assessing nature-of-science literacy as one component of scientific literacy. Journal of Physics Teacher Education Online, 3(4), 3-14.

Williams, P.J., Nguyen, N., \& Mangan, J. (2017). Using technology to support science inquiry learning. Journal of Technology and Science Education, 7(1), 26-57. https://doi.org/10.3926/jotse.234

Yeung-Chung, L. (2007). From a museum demonstration to problem solving: promoting the construction of concepts. Physics Education, 42(4), 378. https://doi.org/10.1088/0031-9120/42/4/007

\author{
Published by OmniaScience (www.omniascience.com) \\ Journal of Technology and Science Education, 2018 (www.jotse.org)
}

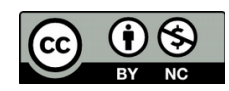

Article's contents are provided on an Attribution-Non Commercial 4.0 Creative commons International License. Readers are allowed to copy, distribute and communicate article's contents, provided the author's and JOTSE journal's names are included. It must not be used for commercial purposes. To see the complete licence contents, please visit https://creativecommons.org/licenses/by-nc/4.0/. 